\title{
How general are current comparative physiology studies? A quantitative review
}

\author{
¿Cuán general son los estudios en fisiología comparada actualmente? \\ Una revisión cuantitativa
}

ROBERTO F. NESPOLO* \& PAULINA ARTACHO

\author{
Instituto de Ecología y Evolución, Facultad de Ciencias, Universidad Austral de Chile, \\ Casilla 567, Valdivia, Chile \\ * Corresponding author: e-mail: robertonespolo@uach.c1
}

\begin{abstract}
Comparative animal physiology and related fields (named here "ecological physiology") are entering a time of synthesis in the form of a quest for large scales patterns. However, these new approaches need to be supplied by great amounts of data, representative of existing animal forms. We tested whether this is the case by performing a quantitative survey in the most important media for ecological physiologists. We found that ecological physiologists have clear biases toward some taxonomic classes, which represent one third of existing animal phyla. Non-taxonomic characterization of animals (endothermy/ectothermy, aquatic/ terrestrial), however, produced a more balanced picture. In addition, ecological physiologists appear to be mostly intraspecific biologists since the great majority of studies were performed in one species. Multispecific studies were the minority and comparable to two - species comparative studies. The later are still being published despite to have been strongly criticized in the past. Cross-tabulation analysis yielded results suggesting that natural populations, vertebrates and terrestrial animals are preferred over artificial populations, aquatic animals and invertebrates. Although we recognize the limitations of our survey, it has the value to indicate that historical biases need to be taken in consideration if more global approaches are being undertaking in this discipline.
\end{abstract}

Key words: comparative physiology, macrophysiology, endotherms, ectotherms, evolutionary physiology, physiological ecology.

\section{RESUMEN}

La fisiología comparada y disciplinas relacionadas (definidas en este trabajo como "ecología fisiológica") han entrado a un período de síntesis en la forma de búsqueda de patrones a gran escala. Sin embargo, dichos enfoques necesitan ser provistos de una gran cantidad de datos que sean representativos de las formas animales existentes. Evaluamos si este es el caso, efectuando una revisión cuantitativa en el medio más importante para los ecólogos fisiológicos. Encontramos que los ecólogos fisiológicos tienen claros sesgos hacia ciertas clases taxonómicas, las cuales representan un tercio de los phyla animales existentes. La caracterización no taxonómica de los animales (endotermia/ectotermia, acuático/terrestre), sin embargo, produjo un panorama más equilibrado. Además, los resultados sugieren que los ecólogos fisiológicos son eminentemente biólogos intraespecíficos pues la gran mayoría de los trabajos fueron estudios de una especie. Los estudios multiespecíficos son minoritarios y comparables en proporción a estudios comparativos entre dos especies. Estos últimos, a pesar de haber sido fuertemente criticados en el pasado, siguen siendo publicados. El análisis de tablas de contigencia sugiere que poblaciones naturales y vertebrados son preferidos por sobre poblaciones artificiales, invertebrados y animales acuáticos. Aunque reconocemos las limitaciones de esta revisión, el presente trabajo sugiere que los sesgos históricos deben considerarse cuando se están originando enfoques más globales dentro de la disciplina.

Palabras clave: fisiología comparada, macrofisiología, endodermos, ectodermos, fisiología evolutiva, fisiología ecológica. 


\section{INTRODUCTION}

"The primary function of schools is to impart enough facts to make children stop asking questions. Some, with whom the schools do not succeed, become scientists"

\section{Schmidt-Nielsen (1998)}

The discipline that we know today as comparative animal physiology has its beginnings in the forties, when a group of physiologists started to ask questions related to whole animals and their physiological capacities related with their environment (Schmidt-Nielsen 1998, Wilmer et al. 2000, Hicks 2002). The mode of action of comparative physiology was declared by Krogh (1929): "for a number of problems there will be some animal of choice, or a few such animals, on which it can be most conveniently studied". This principle has informed and guided investigations in comparative physiology during the last century. Formerly, (and still in many applied field such a biomedical research) animal physiology was relevant only when related with human physiology, and since humans are not available to most of the experiment needed to understand physiological processes, domestic/laboratory animals were used. Hence, a great amount of physiological knowledge was available for a few "model" organisms, and no necessarily related to their natural environment. Probably the second most important tenet in comparative physiology was declared by Garland \& Adolph (1994; see also Felsenstein 1985), when the methodological and philosophical flaws of two species comparative studies were put in evidence.

In present days, comparative physiology is still alive but also it gave birth to a number disciplines that appeared as a result of its fusion with modern ecological and evolutionary theory. It would be appropriate to say that these disciplines are physiological ecology (Sibly \& Calow 1986, McNab 2002), environmental physiology (Willmer et al. 2000) and evolutionary physiology (Feder et al. 2000, Kingsolver \& Huey 2003). The collective was named by Hicks (2002) "ecological physiology". The great majority of the scientific production of these fields is published in specialized journals such as
Physiological and Biochemical Zoology, Functional Ecology, Journal of Experimental Biology, Respiration Physiology, Journal of Experimental Zoology, American Journal of Physiology, and Comparative Biochemistry and Physiology.

Then, it seems clear then that comparative physiology gave rise to a fruitful and interdisciplinary research program. However, how balanced is such knowledge? For instance, did Krogh's principle help to develop a complete and sophisticated picture of how animals work, or did it encourage research in a small fraction of animals? Is ecological physiology a mature discipline, in the sense that it covers equally organisms of different modes of life (aquatic, terrestrial, endotherms, ectotherms) or historical traditions are still important influences on the preferences in the research subjects? Are two-species comparative studies still being published?

To search for answers for such questions we performed a quantitative literature survey. We arbitrarily selected Physiological and Biochemical Zoology (Hicks 2002) as a representative sample of the knowledge in ecological physiology in present days. Hence, on the assumption that published papers in this journal are a good sample of what ecological physiologists are doing today, and how they are doing it, we specifically addressed the following enunciates: (1) research (and hence knowledge) in ecological physiology is homogeneous and representative for all animal types. We characterized "animal type" in four general categories: general taxonomic affiliation (GTA: vertebrate or invertebrate), specific taxonomical affiliation (classes), general mode of life (GML: terrestrial or aquatic) and physiological mode of life (PML: endotherms or ectotherms, see Table 1). (2) comparative physiology is characterized by mono-specific (or intraspecific) studies (Shmidt-Nielsen 1995). However, given that generalization is one of the ultimate aims of science, it would be reasonable to suppose that studies incorporating many species are more general explanations to eco-physiological patterns and processes than one- or twospecies studies. The problem of two species comparative studies was highlighted by the very influential paper of Garland \& Adolph (1994), and solved by the modern methods that 
include phylogenetic relationships explicitly in statistical comparisons (Felsenstein 1985, Blomberg \& Garland 2002). To test if research evolved towards multi-specific studies, we predict that presently multi-species studies ( species comparison category $=\mathrm{SC}$ ) are as common, or at least comparable with onespecies studies. Additionally, as a consequence of the Garland \& Adolph (1994) claim, we predict that no comparisons (or a marginal proportion of frequencies) between two species can be found today in the animal physiological ecology literature.

\section{TABLE 1}

Variables, abbreviations, categories and classification criteria used in the review

Variables, abreviaciones, categorías y criterios de clasificación usados en la revisión

\begin{tabular}{ll}
\hline Variable & Category \\
\hline $\begin{array}{l}\text { General taxonomic } \\
\text { affiliation (GTA) }\end{array}$ & Vertebrate / invertebrate \\
$\begin{array}{l}\text { Specific taxonomic } \\
\text { affiliation (STA) }\end{array}$ & $\begin{array}{l}\text { Classes: mammal, bird, reptile, } \\
\text { amphibian, fish, insect, crustacean, } \\
\text { mollusk, hirudinea or arachnid }\end{array}$
\end{tabular}

Species

comparisons (SC) Monospecific / two - species / three species / multispecific

Base

population (BP) Artificial (two or more generations in artificial settings) / Natural (less than two generations in artificial settings)

General mode of life (GML)

Terrestrial (presents major morphological structures for terrestrial locomotion or flight) / aquatic (major morphological structures for underwater swimming)

Physiological mode

of life (PML) Ectotherm (need external source of heat to maintain body temperature) / endotherm (has an internal source of heat to maintain body temperature)

According to the great advancement of transgenics, genetic engineering and animal breeding designs (Bennett 2003) we would expect that animals from artificial population to have gained representation in ecological physiology literature. Hence, we predict that artificial populations are equally represented in the sampled population than natural populations. We called this category as "base population" (BP: artificial or natural, Table 1).
In addition, by using cross-tabulation and loglinear analysis (Quinn \& Keough 2002), we tested for three null hypotheses regarding specific associations among variables: (1) General taxonomic affiliation is not dependent on base population which in turn is not dependent on general mode of life (in our notation, $\left.\mathrm{H}_{1}=\mathrm{GTA}, \mathrm{BP}, \mathrm{GML}\right)$. The sign of any association between variables is given by marginal tables (see Methods). For instance, suppose that invertebrate comparative physiologists have a tradition (and hence, a tendency) in studying natural populations. This fact would produce (i) a statistically significant association between "general taxonomic affiliation" (vertebrate / invertebrate) with "base population" (artificial / natural, Table 1); and (ii) the examination of the marginal table would indicate a comparatively higher frequency of invertebrate studies performed in natural populations.

Using the same notation and procedures, we will also test the following two hypotheses: $\mathrm{H}_{2}$ $=$ GTA, SC, GML and $\mathrm{H}_{3}=\mathrm{BP}, \mathrm{GML}, \mathrm{PML}$.

\section{MATERIAL AND METHODS}

The complete frequency table is available at: www.nespolo.cl/revision.xls. Every paper was classified according to the criteria of Table 1: general taxonomic affiliation, specific taxonomic affiliation, species comparisons, base population, general mode of life and physiological mode of life. Although the classification of most articles was straightforward, two of the criteria listed in Table 1 required arbitrary considerations to enter in the review. For the case of BP (artificial or natural) we classified as "artificial" those animals that came from a laboratory culture founded at least two generations apart. Hence, many studies performed with individual's long time in captivity were still considered performed in a "natural" population. In the case of GML (terrestrial or aquatic), most animal species fell unambiguously into one of these two categories, but many animals have a hybrid mode of life. We decided to classify as "aquatic" those animals that spend most of their lives in the water, evidenced by conspicuous anatomical modifications for 
underwater swimming (e.g., seals and otters, marine and freshwater turtles, crocodiles and alligators, penguins) and/or animals that need the aquatic medium for reproduction (e.g., amphibians). This criterion excludes marine birds and other diving vertebrates (e.g., marine iguanas, polar bears).

\section{Statistics}

Data was summarized and presented as univariate frequency tables with percentages and cumulative frequencies. To test specific hypotheses regarding the statistical association among categories, we performed cross tabulation and a log-linear analysis with maximum likelihood computation of chi-square statistic using the Statistica 6.1 package, (Quinn \& Keough 2002, StatSoft 2004). Log linear analysis is a sophistication of contingency tables (i.e., analysis of frequencies) suited for several dimensions and interactions. The best model (i.e., the combination of interactions among categories) was searched by (1) testing all k-factor interactions in order of decreasing complexity to determine the maximum levels of interactions supported by the data, and (2) exploring specific combinations of variables in the model by testing all marginal and partial associations. According to these criteria, the model is tested after dropping specific interaction between variables. When this elimination resulted significant (i.e., it significantly decreased the fit), these combinations were kept and when it was not significant (i.e., this term is "redundant") was discarded. After the model was built according to these criteria, was tested with the data. We used both common "Pearson" chi-square and maximum likelihood chi- square statistics (StatSoft 2004). Non-significant models at alpha $=0.05$ were considered statistically supported by the data.

\section{RESULTS AND DISCUSSION}

We reviewed a total of 258 original articles. Reviews, technical reports and commentaries were discarded. Every article was read and classified according to the criteria listed in
Table 1. These criteria avoid structural zeros, which mean that we could not test the null hypothesis of evenness inside the pre-existing taxonomic categories of animals. In the case of the taxonomic class, this fact is itself a general result: there were conspicuous omissions, since nobody has studied and published in Physiological and Biochemical Zoology in the last three years any article in Brachiopoda (lamp shells), Bryozoa, Cnidaria (jellyfishes), Ctenophora (comb jellies), Echinodermata, Nematoda, Nemertea (proboscis worms), Onychophora (velvet worms), Phoronida, Porifera and Rotifera, according to a recent classification (http:// $\mathrm{mclibrary} . \mathrm{nh} \mathrm{m} \mathrm{c} \mathrm{cd.ed} \mathrm{u/t} \mathrm{a} \mathrm{x} \mathrm{o} \mathrm{n} \mathrm{o} \mathrm{m} \mathrm{y} \mathrm{/}$ animalia.html). Also, the resulting frequencies were highly unbalanced toward chordate studies (216 studies, $84.1 \%$ of total), followed by studies in arthropods (33 studies, $12.8 \%$ of total), mollusks ( 7 studies, $2.7 \%$ of total) and annelids ( 1 study, $0.39 \%$ of total). Univariate results for general taxonomic affiliation showed a conspicuous bias towards vertebrate studies $(83.7 \%$ over $16.3 \%$; chi square $(1)=117.4, \mathrm{P}<0.001$, Table 2$)$. This is also reflected in the frequencies of specific taxonomic affiliation that shows mammals as the preferred animal taxa, with $22.1 \%$ of the total (although all vertebrates are approximately well represented, see Table 2), and cephalopods, hirudineans and arachnids as the least studied animals, with less than $0.4 \%$ (Table 3). Hence, in reference to our first question and regarding taxonomic affiliation, ecological physiology is not a balanced knowledge.

\section{TABLE 2}

Frequency table of original articles published in Physiological and Biochemical Zoology from 2001 to present ordered by our category of "general taxonomic affiliation" (see Methods for details)

Tabla de frecuencias de artículos originales publicados en Physiological and Biochemical Zoology desde 2001 al presente, ordenados por la categoría de "afiliación taxonómica general” (ver Métodos para detalles)

\begin{tabular}{lcccc}
\hline Category & Count & Cumulative & Percent & Cumulative \\
\hline Vertebrate & 216 & 216 & 83.7 & 83.7 \\
Invertebrate & 42 & 258 & 16.3 & 100.0 \\
\hline
\end{tabular}


TABLE 3

Frequency table of model taxa that were studied from 2001 to present and published in Physiological and Biochemical Zoology

Tabla de frecuencias de taxa modelos que fueron estudiados desde 2001 al presente y publicados en Physiological and Biochemical Zoology

\begin{tabular}{|c|c|c|c|c|c|}
\hline Class & Phylum & Count & Cumulative & Percent & Cumulative \\
\hline Mammalia & Chordata & 57 & 57 & 22.1 & 22.1 \\
\hline Aves & Chordata & 55 & 112 & 21.3 & 43.4 \\
\hline Reptilia & Chordata & 38 & 150 & 14.7 & 58.1 \\
\hline Osteichthyes & Chordata & 36 & 186 & 14.0 & 72.1 \\
\hline Amphibia & Chordata & 22 & 208 & 8.5 & 80.6 \\
\hline Insecta & Arthropoda & 19 & 227 & 7.4 & 88.0 \\
\hline Crustacea & Arthropoda & 13 & 240 & 5.0 & 93.0 \\
\hline Chrondrichthyes & Chordata & 5 & 245 & 1.9 & 95.0 \\
\hline Bivalvia & Mollusca & 3 & 248 & 1.2 & 96.1 \\
\hline Gastropoda & Mollusca & 3 & 251 & 1.2 & 97.3 \\
\hline Agnatha & Chordata & 3 & 254 & 1.2 & 98.4 \\
\hline Cephalopoda & Mollusca & 1 & 255 & 0.4 & 98.8 \\
\hline Hirudinea & Annellida & 1 & 256 & 0.4 & 99.2 \\
\hline Arachnida & Arthropoda & 1 & 257 & 0.4 & 99.6 \\
\hline Missing & & 1 & 258 & 0.4 & 100.0 \\
\hline
\end{tabular}

However, a possible drawback of our procedure in over- or underestimating studies performed in specific taxa is related with potential author preferences for journals. To check this, we selected the three most frequent authors that appeared in our review: C.M. Wood (ionic regulation in fish: seven articles), G.R Ultsch (physiology of hibernation in turtles: five articles) and T.D. Williams (bird body composition during breeding/migration: four articles) and searched their full scientific production during the time frame of this review. The result was compelling: all three authors published over 30 articles in the last three years in a great variety of journals, being Physiological and Biochemical Zoology a small fraction of them (i.e., there was no preference for Physiological and Biochemical Zoology).

\section{TABLE 4}

Frequency table of original articles published in Physiological and Biochemical Zoology from 2001 to present ordered according to "base population" (see Methods for details)

Tabla de frecuencias de artículos originales publicados en Physiological and Biochemical Zoology desde 2001 al presente, ordenados de acuerdo a "población base" (ver detalles en Métodos)

\begin{tabular}{lcccc}
\hline Category & Count & Cumulative & Percent & Cumulative \\
\hline Natural & 207 & 207 & 80.2 & 80.2 \\
Artificial & 50 & 257 & 19.4 & 99.6 \\
\hline
\end{tabular}

\section{TABLE 5}

Frequency table of original articles published in Physiological and Biochemical Zoology from 2001 to present ordered by our category of "general mode of life" (see Methods for details)

Tabla de frecuencias de artículos originales publicados en Physiological and Biochemical Zoology desde 2001 al presente de acuerdo a la categoría "modo general de vida" (ver detalles Métodos)

\begin{tabular}{lcccc}
\hline Category & Count & Cumulative & Percent & Cumulative \\
\hline Terrestrial & 150 & 150 & 58.1 & 58.1 \\
Aquatic & 108 & 258 & 41.9 & 100.0 \\
\hline
\end{tabular}

Other categorizations of animals yield a different outcome. Terrestrial animals presented a slight but nonsignificant dominance over aquatic animals (58\% versus $42 \%$, chi -square (1) $=6.8, P=0.09$, Table 5). Similarly, ectotherms were slightly better represented than endotherms (57\% versus $43 \%$, chi -square (1) $=4.7, \mathrm{P}=0.034$, Table 6 ).

Then, ecological physiology appears to be representative of animal forms when mode of life (and not taxonomy) is taken into account. Number of species used in the studies is presented in Table 7. Whereas one species studies were the norm (86\%), two species comparative studies was still the second category in this ranking (6.6 $\%)$ which shares this position with multi-specific studies $(6.2 \%)$. Three-species studies were rare 
(1.6\%) (Table 7). Also, studies in natural populations of animals were preferred over artificial populations $(80.2 \%$ over $19.4 \%$, chi square $(1)=96, \mathrm{P}<0.001$, Table 4$)$.

\section{TABLE 6}

Frequency table of original articles published in Physiological and Biochemical Zoology from 2001 to present ordered by our category of "physiological mode of life" (see Methods for details)

Tabla de frecuencias de artículos originales publicados en Physiological and Biochemical Zoology desde 2001 al presente de acuerdo a la categoría "modo fisiológico de vida" (ver detalles en Métodos)

\begin{tabular}{lcccc}
\hline Category & Count & Cumulative & Percent & Cumulative \\
\hline Endotherm & 112 & 112 & 43.4 & 43.4 \\
Ectotherm & 146 & 258 & 56.6 & 100.0
\end{tabular}

\section{TABLE 7}

Frequency table of original articles published in Physiological and Biochemical Zoology from 2001 to present ordered by our category of "species comparison" (see Methods for details)

Tabla de frecuencias de artículos originales publicados en Physiological and Biochemical Zoology desde 2001 al presente de acuerdo a la categoría "comparación de especies" (ver detalles en Métodos)

\begin{tabular}{lcccc}
\hline Category & Count & Cumulative & Percent & Cumulative \\
\hline One-species & 221 & 221 & 85.7 & 85.7 \\
Two-species & 17 & 238 & 6.6 & 92.2 \\
Multi-specific & 16 & 254 & 6.2 & 98.4 \\
Three-species & 4 & 258 & 1.6 & 100.0
\end{tabular}

TABLE 8

Marginal and partial associations among variables for the null hypothesis of independence among general taxonomic affiliation $(=1)$, base population $(=2)$ and general mode of life $(=3)$

Asociaciones parciales y marginales entre variables para la hipótesis nula de independencia entre afiliación taxonómica general $(=1)$, población base $(=2)$ y modo general de vida $(=3)$

\begin{tabular}{cccccc}
\hline Variable & df & Partial association Chi-square & P-value & Marginal association Chi-square & P-value \\
\hline 1 & 1 & 125.0 & $<0.0001$ & 125.0 & $<0.0001$ \\
2 & 1 & 101.2 & $<0.0001$ & 101.2 & $<0.0001$ \\
3 & 1 & 6.5 & 0.01 & 6.5 & 0.01 \\
12 & 1 & 4.2 & 0.04 & 4.3 & 0.04 \\
13 & 1 & 0.1 & 0.72 & 0.2 & 0.63 \\
23 & 1 & 0.8 & 0.36 & 0.9 & 0.33 \\
\hline
\end{tabular}

TABLE 9

Marginal and partial associations among variables for the null hypothesis of independence among general taxonomic affiliation $(=1)$, species comparison $(=2)$, and general mode of life $(=3)$

Asociaciones parciales y marginales entre variables para la hipótesis nula de independencia entre afiliación taxonómica general $(=1)$, comparación de especies $(=2)$ y modo general de vida $(=3)$

\begin{tabular}{cccccc}
\hline Variable & df & Partial association Chi-square & P-value & Marginal association Chi-square & P-value \\
\hline 1 & 1 & 123.8 & $<0.0001$ & 123.8 & $<0.0001$ \\
2 & 3 & 416.1 & $<0.0001$ & 416.1 & $<0.0001$ \\
3 & 1 & 6.7 & 0.01 & 6.7 & 0.01 \\
12 & 3 & 4.0 & 0.26 & 3.9 & 0.28 \\
13 & 1 & 0.4 & 0.53 & 0.3 & 0.59 \\
23 & 3 & 1.3 & 0.73 & 1.2 & 0.76 \\
\hline
\end{tabular}


Marginal and partial associations for each hypothesis (i.e., the model building process) are presented in Tables 8 to 10. For the first and third hypotheses partial association tables suggests two level associations (Tables 8 and 10), whereas for the second hypothesis no associations were found (Table 9). The models we obtained (Table 11) suggest associations among GTA with BP, and GML with PML.

Further examination of marginal tables showed that these associations were produced by a disproportionate frequency of studies performed in natural populations of vertebrates (= 179 studies), compared with the other combined categories of the GTA / BP combination. This also suggests that studies in artificial populations of invertebrates are scarce (= 14 studies). Similarly, marginal tables suggest that the GML / PML interaction occurs because terrestrial studies are more frequently performed in vertebrates than invertebrates $(=$ 100 versus 51 studies), whereas in aquatic environments, invertebrates are preferred $(=97$ versus 13 studies).

\section{CONCLUSIONS}

One of the most noticeable modern trends in ecological physiology is the study of diversity at large scales (Spicer \& Gaston 1999, Chown et al. 2004). Analogous to macroecology (Brown 1999), macrophysiology is the study of of physiological patterns at large scales (Chown \& Nicholson 2004). This novel discipline promotes at least three approaches: geographical variation in physiological traits, taxonomic variation and ecosystem functioning, and scaling and biodiversity (Chown et al. 2004). The success of

TABLE 10

Marginal and partial associations among variables for the null hypothesis of independence among base population $(=1)$, general mode of life $(=2)$ and physiological mode of life $(=3)$

Asociaciones parciales y marginales entre variables para la hipótesis nula de independencia entre afiliación población base $(=1)$, modo general de vida $(=2)$, modo fisiológico de vida $(=3)$

\begin{tabular}{cccccc}
\hline Variable & df & Partial association Chi-square & P-value & Marginal association Chi-square & P-value \\
\hline 1 & 1 & 101.2 & 0.000000 & 101.2 & $<0.0001$ \\
2 & 1 & 6.5 & 0.010987 & 6.5 & 0.01 \\
3 & 1 & 4.7 & 0.030029 & 4.7 & 0.03 \\
12 & 1 & 0.06 & 0.813528 & 0.9 & 0.33 \\
13 & 1 & 1.2 & 0.283218 & 2.0 & 0.15 \\
23 & 1 & 83.2 & 0.000000 & 84.1 & $<0.0001$ \\
\hline
\end{tabular}

TABLE 11

Resulted models obtained by testing partial and marginal associations for each of three multivariate hypotheses enunciated in the introduction (Tables 8,9 and 10)

Modelos resultantes obtenidos por probar asociaciones parciales y marginales para cada una de las 3 hipótesis multivariadas enunciadas en la introducción (Tablas 8,9 y 10 )

\begin{tabular}{lcccc}
\hline Hypothesis tested & Best model & $\begin{array}{c}\text { ML Chi-square } \\
(\text { P-value in parenthesis })\end{array}$ & $\begin{array}{c}\text { Pearson Chi-square } \\
(\text { P-value in parenthesis })\end{array}$ & Degrees of freedom \\
\hline 1. GTA-BP-GML & GTA x BP, GML & $4.7(0.19)$ & $4.6(0.20)$ & 10 \\
2. GTA-SC-GML & GTA, SC, GML & $18.2(0.63)$ & $22.0(0.40)$ & 21 \\
3. BP-GML-PML & GML x PML, BP & $5.0(0.17)$ & $4.3(0.23)$ & 3 \\
\hline
\end{tabular}


macroecology (Brown 1999) suggests that these could be exciting new paradigms, because it adhere ecological physiology to the general trend of synthesis in modern science. However, a good synthesis only can be produced if great amounts of published data available from a variety of organisms. Although our review suggests that ecological physiology is representative of animals in a range of environments and modes of life, there exist great disparities regarding knowledge of different taxonomic affiliations. In fact, we found that ecological physiologists have pervasive preferences (terrestrial vertebrates, aquatic invertebrates). Although a decade ago several authors identified at least four conceptual fronts in ecological physiology (Feder et al. 1987, Garland \& Carter 1994), sometimes the quest for general patterns and principles (e.g., West et al. 1997, Koslowski \& Konarzewski 2004) overlooks the immediate necessities of the field. Our review suggests that in the case of ecological physiology, these necessities encompass a basic physiological knowledge in many animal phyla. Another outcome of this review is that ecological physiologists are mostly intraspecific biologists. Multi -specific studies are scarce, which suggest that ecological physiologists chose- instead to increase the sampling/ experimental effort to make results more general (e.g., Garland \& Ives 2000, AddoBediako et al. 2002) - intraspecific studies to avoid the complications of comparing species (Garland \& Adolph 1994).

Most sciences are historical consequences of socially organized settings (Oreskes 2004). In the case of ecological physiology, history and probably the Krogh principle itself had direct consequences in determining the subject of experimental research. Recently, this principle was extended to artificial man-made animals with the help of trangenics and experimental evolution (Bennett 2003). Perhaps a consequence of this extension is an increasing fraction of studies performed in artificial populations of animals. Hence, knowledge will be progressively more sophisticated, which is good if this growth is representative for all animals forms. If the survey we have undertaken is representative of ecological physiology, we believe this is not the case. Basic questions in comparative physiology (or "physiological natural history") such as ion regulation of jellyfishes, hypoxia adaptation in parasitic worms or energy budget in sea stars are still in the beginnings, and call for more research.

\section{ACKNOWLEDGEMENTS}

This work was funded by DID grant S-200441 and FONDECYT grant 3030032 to R. Nespolo. P. Artacho acknowledges a MECESUP fellowship. This review is in honour to Mario Rosenmann, who encouraged us to see animals as something else than organs and tissues.

\section{LITERATURE CITED}

ADDO-BEDIAKO A, SL CHOWN \& KJ GASTON (2002) Metabolic cold adaptation in insects: a arge-scale perspective. Functional Ecology 16: 332-338.

BENNETT AF (2003) Experimental evolution and the Krogh principle: generating biological novelty for functional and genetic analyses. Physiological and Biochemical Zoology 76: 1-11.

BETTENCOURT BR \& ME FEDER (2002) Rapid concerted evolution via gene conversion at the Drosophila hsp 70 genes. Journal of Molecular Evolution 54: 569-586.

BLOMBERG SP \& T GARLAND (2002) Tempo and mode in evolution: phylogenetic inertia, adaptation and comparative methods. Journal of Evolutionary Biology 15: 899-910.

BROWN JH (1999) Macroecology: progress and prospect. Oikos 87: 3-14.

CHOWN SL \& SW NICOLSON (2004) Insect physiological ecology: mechanisms and patterns. Oxford University Press, New York, New York, USA. 243 pp.

CHOWN SL, KJ GASTON \& D ROBINSON (2004) Macrophysiology: large-scale patterns in physiological traits and their ecological implications. Functional Ecology 18: 159-167.

FEDER ME (1987) Effect of thermal acclimation on locomotor performance in a tropical salamander, Bolitoglossa subpalmata. Physiological Zoology 60: $18-26$.

FEDER ME \& GE HOFMANN (1999) Heat-shock proteins, molecular chaperones, and the stress response: evolutionary and ecological physiology. Annual Reviews of Physiology 61: 243-282.

FEDER ME, AF BENNETT \& RB HUEY(2000) Evolutionary physiology. Annual Review of Ecology and Systematics 31: 315-341.

FELSENSTEIN J (1985) Phylogenies and the comparative method. American Naturalist 125: 1-15.

GARLAND T \& C ADOLPH (1994) Why not to do twospecies comparative studies: limitations on inferring adaptation. Physiological Zoology 67: 797-828

GARLAND T \& P CARTER (1994) Evolutionary physiology. Annual Reviews of Physiology 56: 579-621.

GARLAND T \& AR IVES (2000) Using the past to predict the present: confidence intervals for regression 
equations in phylogenetic comparative methods. American Naturalist 155: 346-364.

GREIG D, EJ LOUIS, RH BORTS \& M TRAVISANO (2002) Hybrid speciation in experimental populations of yeast. Science 298: 1773-1775.

HICKS JW (2002) Editorial. Physiological and biochemical zoology 75: 1-2.

KINGSOLVER J \& R HUEY (2003) Introduction: the evolution of morphology, performance, and fitness. Integrative and Comparative Biology 43: 361-366.

KOZLOWSKI J \& M KONARZEWSKI (2004) Is West, Brown and Enquist's model of allmetric scaling mathematically correct and biologically relevant? Functional Ecology 18: 283-289.

KROGH A (1929) Progress in physiology. American Journal of Physiology 90: 243-251.

MCNAB BK (2002) The physiological ecology of vertebrates. A view from energetics. Cornell University Press, Ithaca, New York, USA. 576 pp.

ORESKES N (2004) A call for a collective. Science 305: 1241-1242.

QUINN GP \& ML KEOUGH (2002) Experimental design and data analysis for biologists. Cambridge
University Press, Cambridge, United Kingdom. 537 pp.

SCHMIDT-NIELSEN K (1995) Animal physiology: adaptation and environment. Cambridge University Press, Cambridge, Massachusetts, USA. 612 pp.

SCHMIDT-NIELSEN K (1998) The camel's nose. Island Press, Washington, District of Columbia, USA. 339 pp.

SIBLY RM \& P CALOW (1986) Physiological ecology of animals. Blackwell Scientific Publications, Oxford, United Kingdom. 179 pp.

SPICER JI \& KJ GASTON (1999) Physiological diversity and its ecological implications. First edition. Blackwell Science, Oxford, United Kingdom. 289 pp.

STATSOFT, INC (2004) STATISTICA (data analysis software system), version $6.1 \mathrm{www}$.statsoft.com.

WEST GB JH BROWN \& BJ ENQUIST (1997) A general model for the origin of allometric scaling laws in biology. Science 276: 122-126.

WILMER P, G STONE \& I JOHNSTON (2000) Environmental physiology of animals. Blackwell Science, Oxford, United Kingdom. 644 pp. 